\title{
Penggunaan Perisian Animasi Interaktif Sel Galvanik dalam Pembelajaran Elektrokimia : Kesan terhadap Pemahaman Konsep Dalam Topik Elektrokimia
}

\author{
Application of Interactive Animation Galvanic Cell Software in the Learning of
} Electrochemistry: Effects on Conceptual Understanding in Electrochemistry

\author{
Lizawati Binti Mohamad Ham ${ }^{1}$ dan Mohamad Syahrizal Bin Ahmad ${ }^{2}$ \\ ${ }^{1}$ Kolej Matrikulasi Perak \\ ${ }^{2}$ Universiti Pendidikan Sultan Idris \\ Corresponding author e-mail :1lizawatimohdham@gmail.com
}

\begin{abstract}
Abstrak
Penggunaan perisian multimedia dalam proses pengajaran dan pembelajaran Kimia dipercayai mampu memberi impak yang positif terhadap pencapaian akademik pelajar. Kajian ini dijalankan untuk menentukan keberkesanan penggunaan perisian Animasi Interaktif Sel Galvanik (AIS-G) berbanding kaedah pengajaran konvensional dalam kalangan pelajar di sebuah Kolej Matrikulasi di Zon Utara, Semenanjung Malaysia. Perisian AIS-G telah direka bentuk menggunakan integrasi model Hanaffin dan Peck dan model ASSURE. Kajian ini merupakan sebuah kajian eksperimen kuasi yang melibatkan seramai 70 orang pelajar aliran Sains, Semester Tiga dari Program Dua Tahun, yang dipilih secara persampelan rawak kelompok. Kumpulan eksperimen menjalankan sesi ulang kaji menggunakan perisian AIS-G sementara kumpulan kawalan menjalankan sesi ulang kaji menggunakan kaedah konvensional. Ujian pra, ujian pasca dan set soal selidik minat digunakan sebagai instrumen. Data dianalisis dengan menggunakan ujian-t dan ujian korelasi Pearson. Analisis ujian-t menunjukkan terdapat perbezaan yang signifikan antara pencapaian ujian pra dengan ujian pasca bagi kumpulan eksperimen $(\mathrm{t}=-14.335, \mathrm{dk}=$ $34, \mathrm{p}=0.000$ ). Bagi kumpulan kawalan pula, tidak terdapat perbezaan yang signifikan antara pencapaian ujian pra dan ujian pasca $(\mathrm{t}=-0.229, \mathrm{dk}=34, \mathrm{p}=0.160)$. Analisis ujian korelasi Pearson menunjukkan terdapat hubungan yang linear positif dan kuat di antara pencapaian ujian pasca dengan minat menggunakan perisian AIS-G bagi pelajar dari kumpulan eksperimen. Kesimpulannya, penggunaan perisian AIS-G dapat dijadikan sebagai salah satu kaedah pengajaran alternatif bagi meningkatkan pencapaian akademik pelajar.
\end{abstract}

Kata Kunci Pembelajaran Kimia, Animasi Interaktif, Sel Galvanik, Elektrokimia

\begin{abstract}
The use of multimedia software in Chemistry teaching and learning process is believed to have a positive impact on students' academic performance. This study was conducted to determine the effectiveness of the use of the Interactive Animation Galvanic Cell (IAGC) software compared to conventional teaching methods among students in a Matriculation College in North Zone, Peninsular Malaysia. IAGC software has been designed using the
\end{abstract}


integration model of Hanaffin and Peck and the ASSURE model. This study is a quasiexperimental study which involved 70 Science students of Semester Three from the TwoYear Program which have been chosen by kluster random sampling. The experimental group undergoes revision sessions using IAGC software while the control group undergoes revision sessions using conventional method. The pre-test, post-test and students' interest questionnaire were used as the instruments. Data were analyzed using t-test and Pearson correlation test. The t-test analysis showed a significant difference between the achievement of pre-test and post-test for the experimental group $(\mathrm{t}=-14335, \mathrm{df}=34, \mathrm{p}=0.000)$. For the control group, there is no significant difference between the achievement of pre-test and post-test $(\mathrm{t}=-0229, \mathrm{df}=34, \mathrm{p}=0.160)$. Pearson correlation analysis showed that there is a strong positive linear relationship between achievement and post-test with students' interest using IAGC software for the experimental group. As a conclusion the IAGC software can be used as an alternative teaching method to increase the students' academic performance.

Keywords Chemistry Learning, Interactive Animation, Galvanic Cell, Electrochemistry

\section{PENGENALAN}

Kimia merupakan salah satu mata pelajaran teras Sains yang wajib diambil oleh semua pelajar jurusan Sains di Kolej Matrikulasi. Secara amnya, mata pelajaran Kimia memerlukan pelajar untuk berfikir secara kreatif dan berimaginasi tinggi (Farizatul, 2011). Ini adalah kerana Kimia mengandungi banyak konsep yang abstrak (Sirhan, 2007; Unce, 2009).

\section{PENYATAAN MASALAH}

Mata pelajaran Kimia seringkali dianggap sebagai satu disiplin ilmu yang sukar dipelajari. Ilmu Kimia bukan sahaja mengandungi fakta Sains semata-mata tetapi juga melibatkan kemahiran matematik yang kukuh terutamanya dalam topik Elektrokimia yang memerlukan pelajar untuk menyeimbangkan persamaan Kimia (Md Nor \& Noor Afiqah, 2010). Maka tidak hairanlah terdapat banyak kajian terdahulu yang mendapati topik Elektrokimia ini suatu topik yang sukar difahami (Butts \& Smith, 1987; Lee \& Kamisah, 2012; Lee \& Kamisah, 2014; Norasiken, 2008; Noor Afiqah, 2008 \& Ogeng' O, 2011) dan melibatkan banyak miskonsepsi (Mohd. Nor \& Mohd. Izhan, 2011; Ogude \& Bradley, 1996; Ozkaya, 2002; Sanger \& Greenbowe, 1997).

Temubual dan tinjauan yang dilakukan oleh Butts dan Smith (1987) ke atas 266 orang pelajar gred 12 di sepuluh buah kolej berdekatan Sydney mendapati konsep perbezaan elektrolit dan bukan elektrolit dalam topik Elektrokimia menduduki tangga ketiga belas dengan peratus kesukaran sebanyak 29\%. Hasil dapatan kajian tinjauan yang dilakukan oleh Ogeng'O (2011) di beberapa buah sekolah menengah di Nairobi, Kenya juga mendapati topik Elektrokimia, Konsep Mol, Kimia Organik, Keradioaktifan dan Perubahan Tenaga merupakan antara topik utama yang paling sukar. Kajian yang dilakukan oleh Norasiken (2008) mendapati Elektrokimia merupakan tajuk ketiga yang dipilih oleh para pelajar dan guru-guru sebagai tajuk yang mempunyai tahap kesukaran yang tinggi. Tinjauan yang dilakukan oleh Lee dan Kamisah (2014) pula mendapati Elektrokimia menduduki tangga kedua tertinggi yang dianggap tajuk yang sukar baik dari persepsi pelajar (min 4.08) mahupun persepsi guru (min 4.57). Ini memberikan gambaran yang jelas bahawa pelajar memerlukan bantuan pembelajaran untuk menguasai Elektrokimia yang bersifat abstrak. 
Berdasarkan kajian-kajian terdahulu terdapat banyak pembelajaran yang dihadapi oleh pelajar bagi topik Elektrokimia. Antaranya ialah masalah penguasaaan pengetahuan asas kimia (Noor Afiqah, 2008), formula kimia, kereaktifan logam mengikut siri Elektrokimia dan cara menulis persamaan sel Kimia (Noor Afiqah, 2008), miskonsepsi dalam memahami pergerakan arus elektrik melalui elektrolit dan titian garam (Sanger \& Greenbowe, 1997), pemahaman yang rendah dalam menulis persamaan kimia elektrolisis leburan dan menerbitkan formula kimia dalam sebatian leburan, penguasaan yang lemah bagi konsep dalam proses elektrolisis dan kekeliruan dalam menulis simbol-simbol Kimia (Mohd Nor \& Mohd Izham, 2011), masalah dalam penulisan persamaan yang seimbang dan menghuraikan proses elektrolisis (Mohd Nor \& Mohd Izham, 2011) dan kurang memahami konsep kekutuban anod dan katod dalam menentukan pergerakan anion dan kation dalam sel elektrolisis (Md Nor \& Noor Afiqah, 2010).

Untuk menguasai konsep-konsep Elektrokimia, pelajar perlu memahami konsepkonsep tersebut daripada tiga aras perwakilan seperti yang telah dicadangkan oleh Johnstone (1993) iaitu aras makroskopik, mikroskopik dan simbolik. Pada aras makrosopik, pelajar perlu membuat pemerhatian dan memahami perubahan-perubahan yang berlaku semasa tindak balas kimia yang berlaku di anod dan katod seperti perubahan warna elektrolit, pembebasan gelembung udara, pembentukan mendakan dan perubahan saiz elektrod (Lee \& Kamisah, 2012). Pada aras mikroskopik pula, pelajar perlu mengimaginasikan pengaliran elektron dalam litar luar, pengaliran ion-ion dalam elektrolit dan tindak balas kimia di anod dan katod semasa proses redoks yang berlaku dalam sel (Lee \& Kamisah, 2012). Pada aras simbolik, pelajar perlu menulis persamaan kimia bagi tindak balas yang berlaku di anod dan katod. Banyak kajian terdahulu berkaitan penggunaan perisian multimedia yang ternyata memberikan impak yang positif terhadap pencapaian pelajar bagi topik Elektrokimia (Hasnira 2005, Lee \& Kamisah, 2012, Noraffandy \& Fatimah, 2012 , Noor Haslina, 2009, Oyeleken \& Olorundare, 2009 , Sanger \& Greenbowe, 1997). Oleh yang demikian, kajian ini dijalankan untuk mengetahui keberkesanan penggunaan perisian Animasi Interaktif Sel Galvanik terhadap prestasi akademik pelajar bagi topik Sel Galvanik.

\section{OBJEKTIF KAJIAN}

Secara umumnya, kajian yang dijalankan bertujuan untuk mengetahui kesan penggunaan perisian Animasi Interaktif Sel Galvanik (AIS-G) dalam pengajaran dan pembelajaran Kimia di peringkat Matrikulasi. Secara khususnya, objektif kajian adalah untuk:

1. mengkaji kesan penggunaan perisian Animasi Interaktif Elektrokimia Sel Galvanik (AIS-G) terhadap pencapaian pelajar Sains Program Dua Tahun Semester 3 di sebuah Kolej Matrikulasi.

2. mengkaji hubungan antara skor min pencapaian dengan minat pelajar terhadap penggunaan perisian Animasi Interaktif Elektrokimia Sel Galvanik (AIS-G) dalam proses pengajaran dan pembelajaran Kimia. 


\section{HIPOTESIS KAJIAN}

Berdasarkan persoalan kajian di atas, hipotesis nul kajian adalah seperti berikut:

$\mathrm{H}_{01}$ : Tidak terdapat perbezaan yang signifikan antara skor min pencapaian ujian pra di antara kumpulan eksperimen dan kumpulan kawalan.

$\mathrm{H}_{02}$ : Tidak terdapat perbezaan yang signifikan antara skor min pencapaian ujian pra dan skor min pencapaian ujian pasca dalam kalangan pelajar bagi kumpulan kawalan.

$\mathrm{H}_{03}$ : Tidak terdapat perbezaan yang signifikan antara skor min pencapaian ujian pra dan skor min pencapaian ujian pasca dalam kalangan pelajar bagi kumpulan eksperimen.

$\mathrm{H}_{04}$ : Tidak terdapat perbezaan yang signifikan antara skor min pencapaian ujian pasca di antara kumpulan eksperimen dan kumpulan kawalan.

$\mathrm{H}_{05}$ : Tidak terdapat perhubungan yang signifikan di antara skor pencapaian ujian pasca dengan minat pelajar terhadap penggunaan perisian Animasi Interaktif Elektrokimia Sel Galvanik (AIS-G) dalam kalangan pelajar-pelajar dari kumpulan eksperimen.

\section{METODOLOGI KAJIAN}

\section{Reka bentuk kajian}

Jenis reka bentuk eksperimen kuasi yang dipilih dalam kajian ini ialah reka bentuk ujian pra - ujian pasca kumpulan kawalan tidak setara (Non-equivalent pre-test and post-test controlled group design). Reka bentuk ini mengandungi dua kumpulan sampel iaitu kumpulan eksperimen dan kumpulan kawalan.

\section{Populasi dan sampel kajian}

Populasi kajian terdiri daripada 196 orang pelajar Sains Semester 3 dari Program Dua Tahun (PDT) di sebuah Kolej Matrikulasi di Zon Utara yang berumur dalam lingkungan 18 - 19 tahun. Sampel kajian dipilih secara persampelan rawak kelompok. Seramai 70 orang pelajar daripada dua kumpulan kelas amali telah terpilih sebagai sampel kajian. Kemudian, pelajar-pelajar tersebut telah dibahagikan kepada dua kumpulan iaitu 35 orang kumpulan kawalan dan 35 orang kumpulan eksperimen.

\section{Instrumen Kajian}

Dalam kajian ini, sebanyak tiga instrumen digunakan untuk mengumpul data. Instrumeninstrumen tersebut ialah ujian pra, ujian pasca dan satu set soal selidik. Kedua-dua set soalan dalam ujian pra dan ujian pasca mempunyai bilangan soalan yang sama dan menguji kefahaman pelajar tentang konsep Sel Galvanik pada tahap kesukaran yang setara. Keduadua ujian tersebut terdiri daripada tiga bahagian iaitu bahagian A, B dan C. Bahagian A mengandungi maklumat latar belakang responden manakala Bahagian B terdiri daripada 15 soalan objektif dengan setiap satu soalan mempunyai empat pilihan jawapan. Soal selidik yang digunakan telah diubahsuai daripada kajian yang dijalankan oleh Hasnira (2005) dengan nilai kebolehpercayaan 0.71 yang diperoleh daripada ujian rintis. Soal selidik ini 
terdiri daripada dua bahagian iaitu Bahagian A dan Bahagian B. Bahagian A memberikan maklumat demografi responden dari segi jantina, bangsa, dan pencapaian mata pelajaran Kimia. Bahagian B pula terdiri daripada 20 item untuk mengukur persepsi pelajar terhadap penggunaan perisian AIS-G semasa mengulangkaji subtopik Sel Galvanik. Soal selidik ini dilengkapi dengan skala likert lima pilihan yang digunakan oleh para pelajar untuk menyatakan darjah persetujuan terhadap setiap item yang dikemukakan.

\section{Kaedah pengumpulan data}

Kajian ini mula dijalankan selepas seminggu topik Elektrokimia telah habis diajar oleh pensyarah kuliah. Ujian pra telah diedarkan kepada kedua-dua kumpulan. Selepas satu minggu berlalu, sesi ulang kaji subtopik Sel Galvanik diadakan bagi kedua-dua kumpulan yang telah dipilih. Para pelajar dari kumpulan eksperimen telah mengulang kaji menggunakan perisian AIS-G. Proses ulang kaji ini dijalankan di makmal komputer. Para pelajar dari kumpulan kawalan turut menjalani sesi ulang kaji menggunakan kaedah pengajaran konvensional iaitu pensyarah mengadakan perbincangan dengan pelajar berdasarkan nota kuliah. Keseluruhan proses ulang kaji bagi setiap kumpulan mengambil masa selama tiga minggu. Ujian pasca telah dijalankan serentak bagi kedua-dua kumpulan pada minggu keempat. Setelah selesai menjawab soalan-soalan ujian pasca, kumpulan eksperimen seterusnya diminta menjawab soal selidik.

\section{Kaedah analisis data}

Semua data yang diperoleh melalui prosedur pengumpulan data telah diproses menggunakan perisian "Statistical Package for Sosial Sciences" (SPSS) versi 19.0 dan dianalisis menggunakan statistik deskriptif iaitu peratus dan statistik inferensi iaitu iaitu ujian- $t$ sampel berpasangan, ujian- $t$ sampel tak bersandar dan ujian korelasi Pearson .

\section{KAJIAN RINTIS}

\section{Kesahan}

Item-item dalam ujian pra dan ujian pasca telah dirujuk dan dinilai oleh dua orang panel pakar. Pakar yang pertama merupakan pensyarah Kimia yang mempunyai pengalaman mengajar mata pelajaran Kimia Matrikulasi melebihi 10 tahun. Isi kandungan bagi ujian pra dan ujian pasca telah disemak dan disahkan agar bersesuaian dengan sukatan pelajaran dan perisian AIS-G yang telah dibangunkan. Dari aspek penggunaan perkataan, ayat, gaya bahasa dan tatabahasa telah disahkan oleh pakar yang kedua yang merupakan pensyarah Bahasa Inggeris yang berpengalaman mengajar mata pelajaran Bahasa Inggeris menghampiri 10 tahun. Darjah persetujuan antara pakar terhadap instrumen tersebut dianalisis berdasarkan pada nilai persetujuan Cohen Kappa. Darjah persetujuan Cohen Kappa bagi ujian pra ialah 0.774 manakala ujian pasca ialah 0.644. Kedua-dua darjah persetujuan ini berada dalam julat 0.61 hingga 0.80 yang menunjukkan persetujuan yang tinggi menurut kajian yang dijalankan oleh Viera dan Garrett (2005). 


\section{Kebolehpercayaan}

Kajian rintis telah dijalankan ke atas 40 orang pelajar dari Program Dua Tahun (PDT) yang tidak dipilih menjadi sampel kajian di kolej matrikulasi yang sama. Setelah proses analisis dilakukan, nilai Alpha Cronbach bagi ujian pra dan ujian pasca ialah 0.788 dan 0.767 , manakala bagi soal selidik minat, nilai Alpha Cronbach juga adalah tinggi iaitu 0.700. Menurut Mohsen dan Dennick (2011), nilai pekali Alpha Cronbach yang diterima ialah di antara 0.70 hingga 0.95 .

\section{Dapatan Kajian}

Berdasarkan analisis deskripsi untuk maklumat demografi, kumpulan eksperimen terdiri daripada $18(51.4 \%)$ orang pelajar lelaki dan $17(48.6 \%)$ orang pelajar perempuan. Kumpulan kawalan pula mengandungi 17 (48.6\%) orang pelajar lelaki dan 18 (51.4\%) orang pelajar perempuan. Ini menunjukkan bilangan pelajar lelaki dan pelajar kumpulan bagi kedua-dua kumpulan adalah hampir setara. Dari aspek tahap kemahiran menggunakan komputer, didapati pelajar-pelajar dari kedua-dua kumpulan mempunyai tahap kemahiran menggunakan komputer yang hampir sama iaitu:

i. kumpulan kawalan :

mahir $(12 ; 34.3 \%)$, sederhana $(12 ; 34.3 \%)$ dan kurang mahir $(11 ; 31.4 \%)$

ii. kumpulan eksperimen :

mahir $(12 ; 34.3 \%)$, sederhana $(11 ; 31.4 \%)$ dan kurang mahir $(12 ; 34.3 \%)$

Berdasarkan kepada analisis ujian- $t$ dalam Jadual 3.1, didapati min ujian pra bagi kumpulan kawalan dan kumpulan eksperimen masing-masing adalah 50.17 dan 50.29 di mana perbezaan minnya ialah - 0.114 , dengan sisihan piawai masing-masing adalah 19.580 dan 19.141. Walaupun terdapat perbezaan skor min ujian pra di antara kumpulan eksperimen dan kumpulan kawalan, namun perbezaan itu tidak signifikan secara statistik apabila nilai $t=-0.025$, dan nilai $p=0.980$, iaitu melebihi nilai signifikan 0.05 yang telah ditetapkan. Oleh itu, hipotesis nul yang pertama gagal ditolak.

Jadual 3.1 Analisis ujian- $t$ bagi ujian pra antara kedua-dua kumpulan

\begin{tabular}{lrrrrrrrr}
\hline \multicolumn{1}{c}{ Kumpulan } & $n$ & Min & $\begin{array}{c}\text { Sisihan } \\
\text { piawai }\end{array}$ & $\begin{array}{c}\text { Beza } \\
\text { min }\end{array}$ & $\boldsymbol{t}$ & dk & $\boldsymbol{p}$ \\
\hline Kawalan & 35 & 50.17 & 19.580 & -0.114 & -0.025 & 68 & 0.980 \\
Eksperimen & 35 & 50.29 & 19.141 & & & \\
\hline
\end{tabular}

Analisis ujian- $t$ sampel-sampel berpasangan seperti dalam Jadual 3.2 di bawah menunjukkan skor min pencapaian ujian pra dan skor min pencapaian ujian pasca bagi kumpulan kawalan masing-masing adalah 50.17 dan 50.40, di mana perbezaan min ialah - 0.229. Sisihan piawai pula masing-masing 19.580 dan 19.863. Didapati, nilai $t=-1.435$, dan $p$ ialah 0.160 , iaitu melebihi aras signifikan 0.05 yang telah ditetapkan. Dengan ini, hipotesis nul yang kedua gagal ditolak. 
Jadual 3.2 Analisis ujian-t sampel pasangan bagi ujian pra dan ujian pasca bagi kumpulan kawalan.

\begin{tabular}{llllccccc}
\hline \multirow{2}{*}{ Kumpulan } & Ujian & $\mathbf{n}$ & min & $\begin{array}{c}\text { Sisihan } \\
\text { piawai }\end{array}$ & $\begin{array}{c}\text { Beza } \\
\text { min }\end{array}$ & $\boldsymbol{t}$ & dk & $\boldsymbol{p}$ \\
\hline \multirow{2}{*}{ Pasangan } & Pra & 35 & 50.17 & 19.580 & -0.229 & -1.435 & 34 & 0.160 \\
& Pasca & 35 & 50.40 & 19.863 & & & \\
\hline
\end{tabular}

Berdasarkan Jadual 3.3 di bawah, analisis ujian- $t$ sampel-sampel berpasangan menunjukkan bahawa skor min pencapaian ujian pra dan skor min pencapaian ujian pasca bagi kumpulan eksperimen masing-masing adalah 50.29 dan 77.20, di mana perbezaan min ialah -26.914. Sisihan piawai pula masing-masing adalah 19.141 dan 8.639. Didapati, nilai $t=-14.335$, dan $p$ ialah 0.00 , iaitu lebih rendah dari aras signifikan 0.05 yang telah ditetapkan. Dengan ini, hipotesis nul yang ketiga berjaya ditolak.

Jadual 3.3 Analisis ujian- $t$ sampel pasangan bagi kedua-dua ujian bagi kumpulan eksperimen

\begin{tabular}{|c|c|c|c|c|c|c|c|c|}
\hline Kumpulan & & $n$ & $\min$ & $\begin{array}{c}\text { Sisihan } \\
\text { piawai }\end{array}$ & $\begin{array}{c}\text { Beza } \\
\text { min }\end{array}$ & $t$ & dk & $p$ \\
\hline \multirow{2}{*}{ Pasangan } & Pra & 35 & 50.29 & 19.141 & \multirow{2}{*}{-26.914} & \multirow{2}{*}{-14.335} & \multirow{2}{*}{34} & \multirow{2}{*}{0.00} \\
\hline & Pasca & 35 & 77.20 & 8.639 & & & & \\
\hline
\end{tabular}

Berdasarkan Jadual 3.4, didapati min ujian pasca bagi kumpulan kawalan dan kumpulan eksperimen masing-masing adalah 50.40 dan 77.20 di mana perbezaan minnya ialah - 26.80, dengan sisihan piawai masing-masing 19.863 dan 8.639. Skor min pencapaian ujian pasca bagi kumpulan eksperimen adalah lebih tinggi berbanding kumpulan kawalan. Ini terbukti apabila perbezaan min antara kedua-dua kumpulan ini adalah besar. Oleh yang demikian, terdapat perbezaan skor min pencapaian ujian pasca yang signifikan secara statistik apabila nilai $t=-7.320$, dan nilai $p=0.00$, iaitu kurang daripada nilai signifikan 0.05 yang telah ditetapkan. Oleh itu, hipotesis nul yang keempat berjaya ditolak.

Jadual 3.4 Analisis ujian- $t$ sampel-sampel bebas bagi ujian pasca bagi kedua-dua kumpulan

\begin{tabular}{lccccccc}
\hline Kumpulan & $\boldsymbol{n}$ & min & $\begin{array}{l}\text { Sisihan } \\
\text { piawai }\end{array}$ & $\begin{array}{l}\text { Beza } \\
\text { min }\end{array}$ & $\boldsymbol{t}$ & dk & $\boldsymbol{p}$ \\
\hline Kawalan & 35 & 50.40 & 19.863 & & & & \\
Eksperimen & 35 & 77.20 & 8.639 & -26.80 & -7.320 & 68 & 0.00 \\
\hline
\end{tabular}

Jadual 3.5 Analisis ujian korelasi Pearson di antara ujian pencapaian pasca dengan minat

\begin{tabular}{ccc}
\hline & \multicolumn{2}{c}{ Ujian Pasca } \\
\hline Minat & Korelasi Pearson & $0.966^{* *}$ \\
& Signifikan (2-tailed) & 0.00 \\
& Bilangan pelajar, N & 35 \\
\hline
\end{tabular}

** Korelasi signifikan pada aras 0.01 (2-tailed) 
Hasil analisis ujian korelasi Pearson antara skor pencapaian ujian pasca dengan minat pelajar menggunakan perisian AIS-G seperti dalam Jadual 3.5 menunjukkan bahawa nilai pekali korelasi Pearson hubungan antara minat menggunakan perisian AIS-G dengan skor pencapaian ujian pasca bagi pelajar-pelajar dari kumpulan eksperimen ialah 0.966 pada aras korelasi signifikan 0.01 , berada dalam julat 0.80 hingga 1.0, yang menunjukkan hubungan yang sangat kuat (Evans \& Over, 1996).

\section{PERBINCANGAN}

Hasil analisis ujian- $t$ sampel-sampel bebas bagi ujian pra menunjukkan tidak terdapat perbezaan yang signifikan ke atas skor min pencapaian ujian pra di antara pelajar dalam kumpulan eksperimen dan kumpulan kawalan apabila nilai $t=-0.025$, dan nilai $p=0.980$, iaitu melebihi nilai signifikan 0.05 yang telah ditetapkan. Hasil kajian juga mendapati bahawa skor min pencapaian ujian pra bagi kumpulan kawalan dan kumpulan eksperimen masing-masing adalah 50.17 dan 50.29 dengan perbezaan minnya ialah - 0.114, dengan sisihan piawai masing-masing adalah 19.580 dan 19.141. Oleh itu, hipotesis nul yang pertama gagal ditolak. Ini menunjukkan bahawa sebelum rawatan dijalankan, kedua-dua kumpulan pelajar ini mempunyai pengetahuan sedia ada dan kebolehan yang setara dalam subtopik Sel Galvanik. Hasil dapatan ini adalah konsisten dengan dapatan kajian yang dilakukan oleh Hasnira (2005), Effandi dan Abd Razak (2006), Noor Haslina (2009), Alvarez (2010) dan Hairiah (2012).

Analisis ujian- $t$ sampel-sampel bebas telah berjaya menolak hipotesis nul yang keempat yang menunjukkan terdapat perbezaan yang signifikan terhadap skor min pencapaian ujian pasca di antara kumpulan eksperimen yang mengulangkaji menggunakan perisian AIS-G dengan kumpulan kawalan yang mengulangkaji secara konvensional. Perbezaan skor min pencapaian ujian pasca ini adalah signifikan secara statistik apabila nilai $t=-7.320$, dan nilai $p=0.00$, iaitu $p<0.05$. Berdasarkan kepada analisis ujian- $t$, didapati min ujian pasca bagi kumpulan kawalan dan kumpulan eksperimen masing-masing adalah 50.40 dan 77.20. Dengan ini, dapatlah disimpulkan bahawa peningkatan skor min pencapaian dalam ujian pasca adalah disebabkan oleh program intervensi yang telah dijalankan dan bukanlah oleh faktor pengetahuan sedia ada pelajar. Hasil dapatan ini adalah berpadanan dengan kajian yang dijalankan oleh Hasnira (2005), Lee dan Kamisah (2012) dan Hairiah (2012).

Analisis ujian- $t$ terhadap hipotesis nul yang kedua mendapati tidak terdapat perbezaan min yang signifikan antara pencapaian ujian pra dengan ujian pasca bagi pelajar dalam kumpulan kawalan apabila nilai $t=-1.435$, dan $p$ ialah 0.160 , iaitu melebihi aras signifikan 0.05 yang telah ditetapkan. Dapatan ini jelas menunjukkan bahawa kaedah mengulangkaji secara konvensional tidak dapat membantu meningkatkan pencapaian akademik pelajar bagi subtopik Sel Galvanik. Dapatan ini mungkin disebabkan oleh nota kuliah yang menjadi sumber rujukan utama pelajar-pelajar semasa mengulang kaji subtopik Sel Galvanik ini tidak melibatkan integrasi ketia-tiga mod iaitu mod makroskopik, mod mikroskopik, dan mod perwakilan. Dapatan kajian ini adalah bertepatan dengan kajian yang dilakukan oleh Hasnira (2005).

Berdasarkan keputusan analisis ujian- $t$ terhadap hipotesis yang ketiga, terdapat perbezaan yang signifikan antara skor min pencapaian ujian pra dan skor min pencapaian ujian pasca dalam kalangan pelajar bagi kumpulan eksperimen apabila nilai $t=-14.335$, 
dan $p$ ialah 0.00 , iaitu lebih rendah dari aras signifikan 0.05 yang telah ditetapkan. Oleh itu, hipotesis nul yang ketiga berjaya ditolak. Ini bermakna, penggunaan perisian AIS-G semasa mengulangkaji subtopik Sel Galvanik dapat memberi kesan positif terhadap pencapaian pelajar.Dapatan kajian ini konsisten dengan dapatan beberapa kajian yang lalu seperti Ezeudu \& Ezinwanne (2013), Hasnira (2005), Khoshouie et al., (2014), Lee (2014), Liao dan Chen (2007), Muzammila et al., (2011), Noor Aini (2010), Noor Haslina (2009), Oyeleken dan Olorundare (2009) dan Sanger dan Greenbowe (1997) yang menjalankan kajian untuk menentukan keberkesanan penggunaan komputer dalam pengajaran dan pembelajaran terhadap pencapaian akademik pelajar.

Analisis korelasi Pearson menunjukkan, terdapat hubungan yang linear positif yang sangat kuat di antara minat menggunakan perisian AIS-G dengan pencapaian akademik pelajar-pelajar dalam ujian pasca. Ini jelas menunjukkan pelajar-pelajar yang menunjukkan minat menggunakan perisian AIS-G untuk mengulang kaji subtopik Sel Galvanik memperolehi skor yang lebih tinggi dalam ujian pencapaian pasca berbanding pelajar pelajar yang tidak menggunakan perisian AIS-G dalam ulang kaji mereka. Hasil dapatan ini adalah sejajar dengan kajian-kajian terdahulu yang telah dilakukan oleh Saridah (2006), Mohd Fairuz, Mohd Bekri, Jamil dan Mohd Salleh (2011), Roslee dan Mohd Saifullah (2013) dan Zakiah (2012).

\section{KESIMPULAN}

Hasil kajian membuktikan bahawa penggunaan AIS-G dalam pembelajaran Elektrokimia berupaya meningkatkan pemahaman konsep Elektrokimia berbanding dengan cara pembelajaran secara konvensional. Dalam kajian ini, perisian AIS-G digunakan sebagai bahan untuk mengulang kaji bagi subtopik Sel Galvanik. Adalah dicadangkan kajian lanjutan, perisian AIS-G ini dapat dijadikan sebagai bantu mengajar yang utama dan diperkenalkan kepada pelajar pada permulaan pengajaran topik Elektrokimia. Penggunaan perisian AIS-G ini pada peringkat awal pengajaran bukan sahaja dapat menarik minat dan tumpuan pelajar dalam proses pengajaran dan pembelajaran bahkan dapat mengelakkan dari berlakunya miskonsepsi. Lampiran menunjukkan beberapa contoh paparan muka perisian AIS-G.

\section{RUJUKAN}

Akram, M., Athar, H. M., \& Ali, M. (2011). The influence of computer assisted instruction (CAI) in chemistry on the students' achievement at higher secondary level. Journal of Social Sciences and Education, 1(4), 426-435.

Alvarez, M. D. (2010). The effect of Computer-Aided Instruction on the academic performance of third year students in Science And Technology III at Cawayan Integrated School, Division of Northern, Samar. Tesis Ijazah Sarjana Pendidikan Seni yang tidak diterbitkan.Filipina :University Of Eastern Philippines.Retrieved October 12 2014, from http://www.academia. edu/3267993/the_effect_of_computer-aided_instruction_on_the_academic_performance of_third_year_students_in_science_and_technology_iii_at_cawayan_integrated_school_ division_of_northern_samar 
Bradley, J. D., \& Ogude, N. A. (1996). Electrode Processes and Aspects Relating to Cell EMF, Current, and Cell Components in Operating Electrochemical Cells: Precollege and College Student Interpretation. J. Chem. Educ, 73(12), 1145.

Butts, B., \& Smith, R. (1987). HSC chemistry students' understanding of the structure and properties of molecular and ionic compounds. Research in Science Education, 17(1), 192-201.

Butts, B., \& Smith, R. (1987). HSC chemistry students' understanding of the structure and properties of molecular and ionic compounds? Journal of Research in Science Education, 17 (1), 192 201. Retrieved October 10, 2014, from http://link.springer.com/article/10.1007\%2FBF023571 87\#page-1

Effandi Zakaria \& Abd Razak Habib. (2006). Kesan pembelajaran koperatif ke atas pelajar matrikulasi dalam mata pelajaran matematik. Jurnal Teknologi, 45(E), 43 - 62. Retrieved November 3, 2014, from file:///C:/Users/User/Downloads/347-344-1-PB.pdf

Evans, J. S. \& Over, D. E.(1996). Rationality and reasoning. UK: Psychology Press.

Ezeudu, F. O. \& Ezinwanne, O. P. (2013). Effect of simulation on students' achievement in senior secondary school chemistry in enugu east local government area of enugu state, nigeria. Journal of Education and Practice, 4 (19), 84 - 90. Retrieved October 21, 2014, from file://C:/Users/ User/Downloads/7864-9917-1-PB.pdf

Farizatul Laili Md. Johari (2011). Penggunaan perisian agen pedagogi animasi bagi mata pelajaran Kimia Tingkatan Empat untuk subtopik elektrolisis dalam industri. Disertasi Ijazah Sarjana Muda yang tidak diterbitkan. Johor : Universiti Teknologi Malaysia.

Hairiah Munip. (2012). Aplikasi pendekatan konstruktivisme dalam reka bentuk pengajaran berasaskan komputer: Pengaruhnya terhadap pencapaian berdasarkan aras kognitif pelajar. Persidangan Kebangsaan Pembangunan dan Pendidikan Lestari, 100-118, Retrieved October 20, 2014 from http://ipgktb.edu.my/lestari/ipglestari/kertas_lestari2012/Hairiah\%20binti\%20 Munip.pdf

Hasnira Embong. (2005). Pembinaan dan keberkesanan penggunaan perisian multimedia elektrokimia dalam pengajaran dan pembelajaran kimia Tingkatan 4. Tesis Ijazah Sarjana Pendidikan yang tidak diterbitkan. Tanjung Malim: Universiti Pendidikan Sultan Idris

Hussein, S. (2006). Keberkesanan Penggunaan Perisian Multimedia Dalam Pengajaran Dan Pembelajaran Lokus Dalam Dua Matra Terhadap Pelajar Tingkatan Dua. Fakulti Sains: Open University Malaysia.

Johari, F. L. M., Laini, F., Hamid, A., \& Tiawa, D. (2011). Pembangunan perisian agen pedagogi animasi bagi matapelajaran Kimia tingkatan 4 untuk subtopik elektrolisis dalam industri. (Doctoral dissertation, Universiti Teknologi Malaysia).

Johnstone, A. H. (1993). The development of chemistry teaching: A changing response to changing demand. J. Chem. Educ, 70(9), 701.

Johnstone, A. H. (1993). The development of chemistry teaching: A changing response to changing demand. Journal of Chemical Education, 70(9), 701 - 705. Retrieved September 20, 2014 from doi: 10.1021/ed070p701

Khoshouie, E., Ayub, A. F. M., \& Mesrinejad, F. (2014). Molecular workbench software as computer assisted instruction to aid the learning of chemistry. Journal of Educational and Social Research, 4(3), 373.

Khoshouie, E., Ayub, A.F.M., \& Mesrinejad, F. (2014). Molecular Workbench Software as Computer Assisted Instruction to Aid the Learning of Chemistry. Journal of Educational and Social Research, 4 (3), 373 - 379. Retrieved October 18, 2014 from doi:10.5901/jesr.2014.v4n3p373

Lee, T. T. \& Kamisah Osman. (2012). Penggunaan modul multimedia interaktif dengan agen pedagogi dalam pembelajaran elektrokimia: Kesan terhadap Pemahaman Konsep dalam Elektrokimia. Sains Malaysiana, 41 (10), 1301 - 1307. Retrieved October 18, 2014 fromhttp:// www.ukm.my/jsm/malay_journals/jilid41bil10_2012/Jilid41Bil10_2012ms1301-1307.html 
Lee, T. T., \& Kamisah, O. (2014). Development of interactive multimedia module with pedagogical agent (IMMPA) in the learning of electrochemistry: Needs assessment. Research Journal of Applied Sciences, Engineering and Technology, 7(18), 3725-3732.

Lee, T. T., \& Osman, K. (2012). Penggunaan Modul Multimedia Interaktif dengan Agen Pedagogi dalam Pembelajaran Elektrokimia: Kesan terhadap Pemahaman Konsep dalam Elektrokimia. Sains Malaysiana, 41 (10), 1301-1307.

Lee T. T. \& Kamisah Osman. (2014). Development of Interactive Multimedia Module with Pedagogical Agent (IMMPA) in the Learning of Electrochemistry: Needs Assessment. Journal of Applied Sciences, Engineering and Technology, 7(18), 3725-3732. Retrieved October 18, 2014 fromhttp://maxwellsci.com/print/rjaset/v7-3725-3732.pdf

Liao, Y. K. \& Chen, Y. W. (2007). The Effect of Computer Simulation Instruction on student learning: A Meta-analysis of studies in Taiwan. Journal of Information Technology and Applications, 2(2), 69-79. Retrieved October 12, 2014 from http://jita.csi.chu.edu.tw/Jita_web/publish/ vol2_num 2/04-The\%20Effect\%20of\%20Computer\%20Simulation $\% 20$ Instruction $\% 20$ on $\% 20$ Student $\% 20$ Learning0.pdf

Liao, Y. K., \& Chen, Y. W. (2007). The effect of computer simulation instruction on student learning: A meta-analysis of studies in Taiwan. Journal of information Technology and Applications, 2 (2), 69-79.

Md Nor Bakar \& Noor Afiqah Binti Mustafa (2010). Masalah Pembelajaran Tajuk Elektrokimia Dalam kalangan Pelajar Sekolah Menengah Dalam Konteks Penyelesaian Masalah. Retrieved October 10, 2014 from http://eprints.utm.my/11036/1/Masalah_Pembelajaran_Tajuk_ Elektrokimia_Di_Kalangan_Pelajar_Sekolah_Menengah_Dalam_Konteks_Penyelesaian_ Masalah.pdf

Mohd Fairuz Marian, Mohd Bekri Rahim, Jamil Abd Baser dan Mohd Salleh Tahar. (2011). Keberkesanan penggunaan CD Interaktif Lukisan Isometrik terhadap kemahiran visualisasi pelajar.Persidangan Kebangsaan Penyelidikan Dan Inovasi Dalam Pendidikan Dan Latihan Teknik Dan Vokasional. Retrieved November 2, 2014 from http://eprints.uthm.edu.my/2560/1/ keberkesanan_penggunaan_cd_interaktif.pdf

Mohd Nor Bakar \& Mohd Izham Mukhtar. (2011). Masalah yang dihadapi dikalangan pelajar Tingkatan 4 dalam proses pembelajaran elektrolisis leburan berdasarkan matapelajaran Kimia KBSM. Journal of Educational Social Science, 1, 96 - 120. Retrieved October 10, 2014 fromhttp://eprints.utm.my/12146/1/JSS-2011-1-007.pdf

Mohsen, T. \& Dennick, R. (2011). Making sense of Cronbach's alpha. International Journal of Medical Education, 2, 53-55. Retrieved September 20, 2014 fromdoi: 10.5116/ijme.4dfb.8dfd

Munip, H. (2007). Aplikasi pendekatan konstruktivisme dalam reka bentuk pengajaran berasaskan komputer: pengaruhnya terhadap pencapaian dan motivasi pelajar (Doctoral dissertation, Fakulti Sains dan Teknologi, Universiti Pendidikan Sultan Idris).

Mustafa, N. A. (2008). Masalah pembelajaran tajuk elektrokimia di kalangan pelajar sekolah menengah dalam konteks penyelesaian masalah (Doctoral dissertation, Universiti Teknologi Malaysia).

Muzammila Akram, Hafiz Muhammad Athar \& Murad Ali. (2011). The Influence of Computer Assisted Instruction (CAI) in Chemistry on the Students Achievement at Higher Secondary Level. International Journal of Social Sciences and Education, 1 (4), 426-435. Retrieved October 18, 2014 fromhttp://ijsse.com/sites/default/files/issues/2011/v1i4/paper\%2010/ paper\%2010.pdf

Noor Afiqah Mustafa. (2008). Masalah pembelajaran tajuk elektrokimia dalam kalangan pelajar sekolah menengah dalam konteks penyelesaian masalah. Disertasi Ijazah Sarjana Muda yang tidak diterbitkan. Johor: Universiti Teknologi Malaysia. Retrieved September 20, 2014 from http://www.fp.utm.my/ePusatSumber/pdffail/ptkghdfwP2/p_2008_8130_ d4e3ac3117ff4b81bf703a005daf7212.pdf 
Noor Aini Abdul Majid (2010). Keberkesanan penggunaan animasi dan simulasi berbanding kaedah pengajaran konvensional untuk topik penghibridan dalam kalangan pelajar bumiputera di sebuah Kolej Matrikulasi.Tesis Ijazah Sarjana yang tidak diterbitkan. Tanjung Malim : Universiti Pendidikan Sultan Idris.

Noor Haslina Ahmad (2009). Pembinaan dan keberkesanan koswer pembelajaran amali berbantukan komputer bagi sel elektrokimia : Kimia Matrikulasi. Tesis Ijazah Sarjana yang tidak diterbitkan. Tanjung Malim : Universiti Pendidikan Sultan Idris.

Noraffandy Yahaya \& Fatimah Hishamuddin. (2012). Pembangunan dan penilaian koswer multimedia bagi topik elektrokimia berdasarkan pendekatan inkuiri. Journal of Science and Mathematics Education, 6, 14 - 25.

Norasiken, B. (2008). Makmal Maya Kimia Berasaskan Pendekatan Kognitivisme, Konstruktivisme Dan Konteksual (VLAB-CHEM) (Doctoral dissertation, Universiti Kebangsaan Malaysia).

Norasiken Bakar. (2008). Makmal Maya berasaskan pendekatan Kognitivisme, konstruktivisme dan kontekstual (VLab-Chem).Tesis Doktor Falsafah yang tidak diterbitkan.Bangi : Universiti Kebangsaan Malaysia.

Ogeng'O, E. (2011). Exploration of topic areas that teachers and students perceive difficult in chemistry at secondary level in Nairobi (Kenya). Unpublish Masters Thesis. University of Kenyata, Kenya.

Ogude, N. A. \& Bradley, J. D. (1996). Electrode processes and aspects relating to cell emf, current, and cell components in operating electrochemical cells: precollege and college student interpretation. Journal of Chemistry Education, 73 (12), 1145. Retrieved September 20, 2014 from doi :10.1021/ed073p1145

Oyelekan, O. S., \& Olorundare, A. S. (2009). Development and validation of a computer instructional package on electrochemistry for secondary schools in Nigeria. International Journal of Education and Development using ICT, 5(2).

Oyeleken, O. S. dan Olorundare, A. S. (2009). Development and validation of a computer instructional package on electrochemistry for secondary schools in Nigeria. International Journal of Education and Development using ICT, 5(2). Retrieved October 18, 2014 from http://ijedict.dec.uwi.edu/viewarticle.php?id=677\&layout=html

Ozkaya,A.R. (2002). Conceptual difficulties experienced by prospective teachers in electrochemistry: half-cell potential, cell potential, and chemical and electrochemical equilibrium in galvanic cells. Journal of Chemical Education, 79. Retrieved September 20, 2014 from doi: 10.1021/ ed079p735

Roslee Taip \& Mohd Saifullah Md Sabri.(2013). Penggunaan aplikasi Google Earth dalam meningkatkan prestasi mata pelajaran Geografi di Sekolah Menengah. Seminar Pendidikan Sejarah dan Geografi UMS, 266 - 276.Retrieved November 2, 2014 fromhttp://www.ums. edu.my/fpp/images/stories/Document/SPSG2013/tahap\%20penggunaan $\% 20$ aplikasi $\% 20$ google $\% 20$ earth $\% 20$ dalam $\% 20$ meningkatkan $\% 20$ prestasi $\% 20$ pelajar $\% 20$ mata $\% 20$ pelajaran $\% 20$ geografi\%20di\%20sekolah\%20menengah\%20dr\%20roslee_ums.pdf

Sanger, M. J, \& Greenbowe, T. J., (1998).Common student misconceptions in electrochemistry: Galvanic, electrolytic, and concentration cells. Journal of Research Sciend Teaching, 34 (4), 377 398. Retrieved October 19, 2014 from doi: 10.1002/(SICI)1098-2736(199704)34:4<377::AIDTEA7>3.0.CO;2-O

Sanger, M. J., \& Greenbowe, T. J. (1997). Students' misconceptions in electrochemistry: Current flow in electrolyte solutions and the salt bridge. Journal of Chemical Education, 74(7), 819823. Retrieved October 19, 2014 from http://search.proquest.com/docview/212036463?accou ntid $=13155$

Sanger, M. J., \& Greenbowe, T. J. (1997). Students' misconceptions in electrochemistry regarding current flow in electrolyte solutions and the salt bridge. J. Chem. Educ, 74(7), 819. 
Saridah Hussein. (2006). Keberkesanaan penggunaan perisian multimedia dalam pengajaran dan pembelajaran Lokus dalam dua matra terhadap pelajar Tingkatan Dua. Disertasi Sarjana Muda Pendidikan (Matematik) yang tidak diterbitkan.Universiti Terbuka Malaysia. Retrieved November 2, 2014 from http://eprints.oum.edu.my/175/1/Perisian_multimedia.pdf

Sirhan, G. (2007). Learning difficulties in chemistry: An overview. Journal of Turkish science education, 4(2), 2.

Sirhan, G. (2007). Learning difficulties in Chemistry: An Overview. Journal of Turkish Science Education, 4(2), 2 - 20. Retrieved September 21, 2014 from http://www.tused.org/internet/ tufed/arsiv/v4/i2/metin/tusedv4i2s1.pdf

Tavakol, M., \& Dennick, R. (2011). Making sense of Cronbach's alpha. International journal of medical education, 2, 53.

Uce, M. (2009). Teaching the mole concept using a conceptual change method at college level. Education, 129(4), 683-692.

Viera, A. J., \& Garrett, J. M. (2005). Understanding interobserver agreement: The Kappa Statistic. Family Medicine, 37 (5), 360 - 363. Retrieved September 20, 2014 from http://virtualhost. cs.columbia.edu/ julia/courses/CS6998/Interrater_agreement.Kappa_statistic.pdf

Viera, A. J., \& Garrett, J. M. (2005). Understanding interobserver agreement: the kappa statistic. Fam Med, 37(5), 360-363.

Zakaria, E., \& Habib, A. R. (2006). Kesan Pembelajaran Koperatif Ke Atas Pelajar Matrikulasi dalam Mata Pelajaran Matematik. Sains Humanika, 45(1).

Zakiah Osman. (2012) Persepsi pelajar terhadap penggunaan bahan bantu mengajar berasaskan multimedia interaktif dalam pengajaran. Prosiding POLIMAS, 1 (9), 56 - 59. Retrieved November 2, 2014 from http://www.polimas.edu.my/web4/images/inovasi/pg\%2056\%20 ZAKIAH_JTMK_KOLOKIUM_EDITED.pdf

Özkaya,A.R.(2002). Conceptual difficulties experienced by prospective teachers in electrochemistry: Half-cell potential, cell potential, and chemical and electrochemical equilibrium in galvanic cells. J. Chem. Educ, 79(6), 735. 


\section{LAMPIRAN}
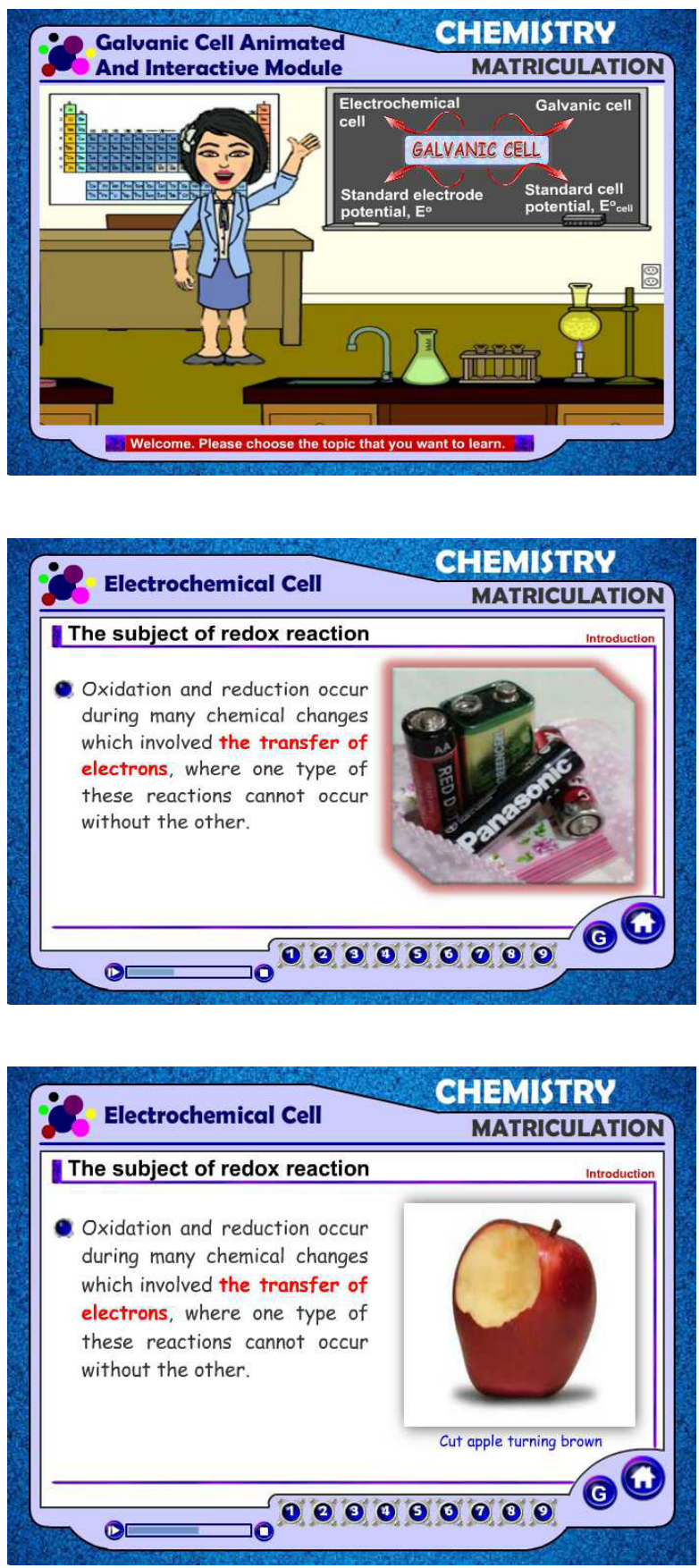

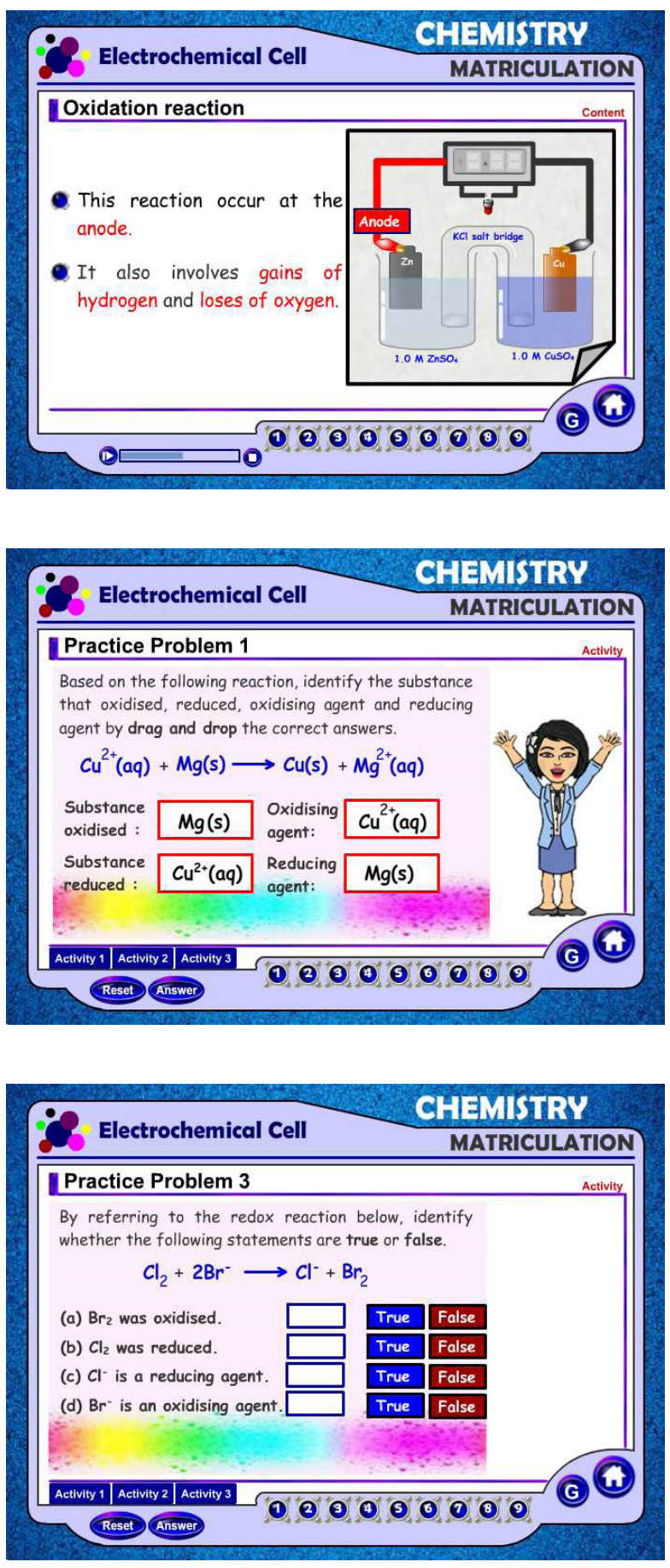
ISSN 2462-2052

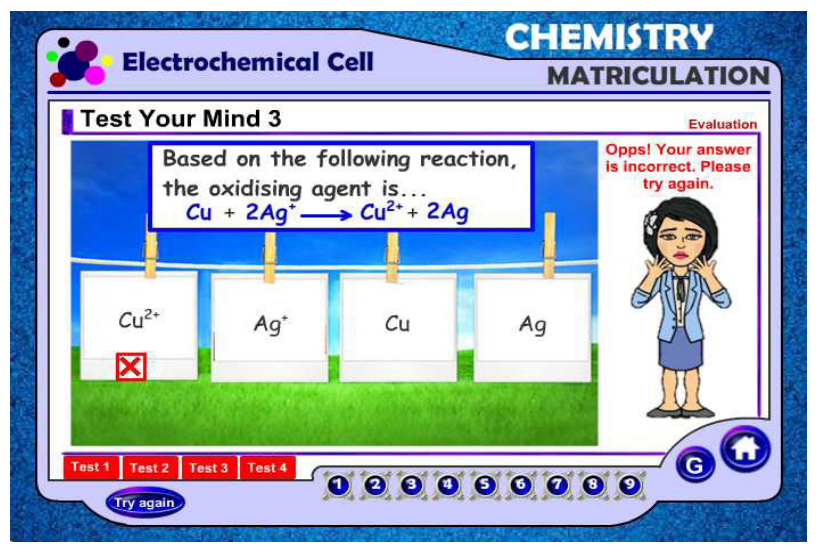

